\title{
RISALAH|
}

DOI: $10.24014 /$ jdr.v30i1.6877

\section{KETERAMPILAN KOMUNIKASI INTERPERSONAL PEKERJA SOSIAL DALAM MENANGANI PENGEMIS DI IPSM YOGYAKARTA}

\author{
Moralely Hendrayani \\ Fakultas Interdisciplinary Islamic Studies (IIS) \\ Universitas Islam Negeri Sunan Kalijaga Yogyakarta \\ Email: moralely05@gmail.com
}

\begin{tabular}{l}
\hline Kata kunci \\
Keterampilan \\
Komunikasi \\
Interpersonal, Pekerja \\
Sosial, Pengemis
\end{tabular}

Keywords

Interpersonal

Communication Skill,

Social Workers,

Beggars

\begin{abstract}
Abstrak
Kemiskinan merupakan permasalahan klasik yang menghinggapi berbagai negara dan tampaknya menjadi persoalan aktual pada masa mendatang. Dampak dari kemiskinan tersebut adalah munculnya pengemis. Dalam hal ini, permasalahan sosial seperti pengemis yang ada di perkotaan terdapat pula di Yogyakarta. Maka dari itu dibutuhkan kerja sama dari pemerintah ataupun non-pemerintah untuk mengurangi pengemis. Saat ini, pemerintah melalui Ikatan Pekerja Sosial Masyarakat (IPSM), salah satu lembaga sosial di Yogyakarta yang bersama-sama mengurangi tingkat pengemis melakukan penanganan yang di adakan setiap minggunya. Para pekerja sosial harus mempunyai keahlian komunikasi interpersonal agar bisa berkomunikasi dengan para pengemis. Metode yang digunakan dalam penulisan adalah kualitatif deskriptif. Hasil penelitian menunjukkan bahwa pengemis yang dimintai data dan di arahkan untuk mengikuti pelatihan telah bersedia dipulangkan ke daerah asalnya, di karenakan para pekerja sosial yang ada di IPSM melakukan pendekatan dengan cara komunikasi interpersonal dengan menggunakan bahasa daerah untuk mendekati para pengemis serta secara tatap muka dan berpenampilan seperti masyarakat biasa serta tidak menggunakan atribut IPSM.
\end{abstract}

\begin{abstract}
Poverty is a classic problem that plagues various countries and seems to be an actual change in the future. The impact of poverty is the emergence of beggars. In this case, social problems such as beggars in urban areas are also happen in Yogyakarta. Therefore, cooperation from government or non-government is needed to reduce beggars. At present the government through the Society of Social Workers Association (IPSM) is one of the social institutions in Yogyakarta which together reduces the level of beggars through handling held every week. The social workers must have the skills of interpersonal communication in order to communicate with beggars. The method used in writing is descriptive qualitative. The results showed that beggars were asked for data and directed to take part in the training and would be sent home in their original areas, because social workers at IPSM has using the interpersonal communication using local language and face to face in order to approach beggars and look like ordinary people and does not use IPSM attributes.
\end{abstract}




\section{Pendahuluan}

Kemiskinan merupakan salah satu persoalan mendasar yang menjadi pusat perhatian pemerintah di negara manapun. Berawal dari sekedar ketidakmampuan memenuhi kebutuhan konsumsi dasar dan memperbaiki keadaan hingga pengertian yang lebih luas yang memasukkan komponen-komponen sosial dan moral, kemiskinan timbul oleh karena minimnya penyediaan lapangan kerja di berbagai sektor, baik sektor industri maupun pembangunan. Senada dengan pendapat di atas adalah bahwasanya kemiskinan ditimbulkan oleh ketidakadilan faktor produksi atau kemiskinan adalah ketidakberdayaan masyarakat terhadap sistem yang diterapkan oleh pemerintah sehingga mereka berada pada posisi yang sangat lemah dan tereksploitasi. Arti definitif ini lebih dikenal dengan kemiskinan struktural. Kemiskinan merupakan gambaran kehidupan di banyak negara berkembang yang mencakup lebih dari satu milyar penduduk dunia.

Kemiskinan juga masalah yang menyangkut banyak aspek karena berkaitan dengan pendapatan yang rendah, buta huruf, derajat kesehatan yang rendah dan ketidaksamaan derajat antar jenis kelamin serta buruknya lingkungan hidup. Salah satu dampak dari kemiskinan tersebut adalah munculnya pengemis. Pengemis menurut Peraturan Kepala Kepolisian (Perkap) Negara Republik Indonesia Tahun 2007 tentang Penanganan Pengemis pada Pasal ayat (2) sebagai orang yang mencari penghasilan dengan meminta-minta di tempat umum dengan berbagai cara dan alasan untuk mendapatkan belas kasihan orang lain. Tidak hanya pengemis tetapi orang yang mempekerjakan orang lain untuk meminta minta juga telah terdapat UU yang mengatur sebagai upaya pemerintah untuk mengurangi pengemis (Khan MM dkk, 2016)

Pengemis yang ada di Yogyakarta disebabkan oleh budaya masyarakat yang malas bekerja dan berpendapat bahwa mengemis bisa menjadi mata pencaharian yang tidak banyak mengeluarkan tenaga dan modal (Tangdilintin, 2000). Pengemis muncul karena kurangnya sumber daya manusia (SDM) yang lemah dan lebih senang dengan keadaan yang memintaminta, sehingga dapat menghasilkan uang dengan gampang. Penyebab kemiskinan berasal dari internal (keterbatasan pendidikan, pengetahuan, akses kesehatan, kurang memiliki keterampilan memberdayakan potensi) dan eksternal (kebijakan pemerintah, bencana sosial dan alam yang terjadi). (Departemen Sosial RI, 2007). Namun beberapa masyarakat juga mengatakan lapangan kerja yang sulit dengan banyaknya persyaratan yang membuat mereka tidak di terima di tempat kerja juga mendorong mereka untuk meminta-minta (Oktaviana dkk, 2014). Berdasarkan faktor-faktor di atas menyebabkan permasalahan-permasalahan sosial seperti pengemis yang ada di perkotaan (Muslimin, 2015) khususnya di Kota Pariwisata Yogyakarta. Menurut data Dinas Sosial DIY, dari tahun 2013 hingga akhir September 2017 tercatat 752 pengemis yang mendapatkan asesmen dari dinas terkait. Sebenarnya Pemerintah Daerah Yogyakarta sudah mengeluarkan Peraturan Daerah (Perda) Nomor 1 Tahun 2014 tentang Penanggulangan Pengemis, hal ini dilakukan sebagai upaya DIY bebas dari pengemis (Irwan dkk, 2016).

Perhatian pemerintah dan masyarakat secara umum terhadap perlunya standar kehidupan yang lebih baik, telah mendorong terbentuknya berbagai usaha kesejahteraan sosial. Dalam penyelenggaraan kesejahteraan sosial, diperlukan peran masyarakat yang 
seluas-luasnya, baik perseorangan, keluarga, organisasi keagamaan, organisasi sosial kemasyarakatan, lembaga swadaya masyarakat, organisasi profesi, badan usaha, lembaga kesejahteraan sosial, maupun lembaga kesejahteraan sosial asing demi terselenggaranya kesejahteraan sosial yang terarah, terpadu, dan berkelanjutan.

Maka dari itu dibutuhkan kerja sama dari pemerintah ataupun non pemerintah untuk mengurangi gelandangan dan pengemis tersebut. Saat ini, pemerintah DIY melalui Ikatan Pekerja Sosial Masyarakat sebagai salah satu lembaga sosial bersama-sama mengurangi tingkat pengemis melalui penanganan yang di adakan setiap minggunya, guna meminimalkan tingkat pengemis dan gelandangan yang khususnya terdapat di Yogyakarta. Hal ini dilakukan melalui pekerja sosial yang bertugas dalam penanganan pengemis, yang mana pekerja sosial merupakan bidang keahlian yang memiliki kewenangan untuk melaksanakan berbagai upaya guna meningkatkan kemampuan orang dalam melaksanakan fungsi-fungsi sosialnya melalui interaksi, agar orang dapat menyesuaikan diri dengan situasi kehidupannya secara memuaskan (Barsky, 2010). Keberfungsian sosial merupakan maksud dari profesi pertolongan pekerjaan sosial (Suharto, 2009).

Dalam hal ini pekerja sosial menjadi pekerja yang mempunyai kualifikasi yang mumpuni sehingga menjadikan tenaga profesional yang tidak hanya bidang akademisi tetapi di lapangan juga bisa menjalankan tugas dan fungsinya dengan baik (Taftazani, 2014). Pekerja sosial dilatih untuk menegakkan serangkaian nilai-nilai terkemuka yang berfokus pada kesetaraan sosial, hak kesejahteraan, hak asasi manusia, diskriminasi, dan penindasan (Derek, 2015). Pekerja sosial dipandang sebagai sebuah bidang keahlian (profesi), yang berarti memiliki landasan keilmuan dan seni dalam praktik (dicirikan dengan penyelenggaraan pendidikan tinggi), sehingga muncul juga definisi pekerja sosial sebagai profesi yang memiliki peranan paling penting dalam domain pembangunan kesejahteraan sosial.

Pada kenyataannya, misi pekerjaan sosial memberikan arah bagi tujuan profesional mereka. Tujuan pekerjaan sosial mengarahkan pada kegiatan-kegiatan mereka ketika pekerja sosial bekerja dengan klien untuk mengembangkan solusi dalam konteks suatu kontinum kekuatan dan kebutuhan. Pekerjaan sosial juga memperkuat keberfungsian manusia dan meningkatkan efektivitas struktur-struktur yang ada di dalam masyarakat yang menyediakan sumber-sumber dan kesempatan-kesempatan kepada anggota masyarakat. Tujuan lain adalah memberikan kesempatan-kesempatan kepada individu, kelompok dan masyarakat untuk dapat mengoptimalkan pemanfaatan sistem-sistem sumber yang telah ada di lingkungan mereka tetapi mereka tidak tahu bagaimana cara mengakses sistem sumber tersebut. Melalui Ikatan Pekerja Sosial Masyarakat (IPSM) yang terbentuk berdasarkan AD/ART yang awalnya bernama FK-PSM (Forum Komunikasi Pekerjaan Sosial Masyarakat) pada tanggal 8 april 1988, berdasarkan SK Walikota no. 500 tahun 2013 berganti nama yang awalnya FK-PSM menjadi IPSM dalam SK Kepala Dinsosnakertrans no. 252 tahun 2013. Di kota Yogyakarta terdapat puluhan Pekerja Sosial Masyarakat (PSM) yang tersebar di seluruh wilayah dari 45 kelurahan dan 14 kecamatan. Saat ini anggota Ikatan Pekerja Sosial Masyarakat (IPSM) khususnya Kota Daerah Istimewa Yogyakarta sudah mencapai 70 orang bekerja full time yaitu seorang koordinator program, seorang tenaga keuangan dan tenaga 
administrasi yang keseluruhannya adalah anggota Pekerja Sosial Masyarakat (PSM). (Kasman, 2018).

Dalam menjalankan tugasnya para pekerja sosial dituntut untuk memiliki keterampilan yang menjadi memiliki ilmu sebagai dasar, karena wawasan yang benar akan menuntun pada tindakan yang benar. Socrates mengatakan "seseorang yang mengetahui apa yang baik, akan berbuat baik" (Gaarder, 2015). Seorang yang terampil pastilah memiliki ilmu, ilmu tersebut jelas tergambar dalam keterampilan yang dia kuasai. Namun di sisi lain, seseorang yang memiliki ilmu belum tentu dapat terampil dalam mempraktikkannya, namun tetap dia mengetahui kebenaran ilmu tersebut. Ilmu diasah dengan fikir, keterampilan diasah dengan gerak (Jahidin, 2016). Keterampilan dalam tindakan intervensi pekerja sosial adalah melakukan perubahan pada level mikro, mezzo dan makro 5 pada umumnya menggunakan metode case work dalam menolong individu dan keluarga secara kasus-perkasus. Sementara Midgley dalam Abdul Najib, menjelaskan bahwa sifat dasar yang penting mengenai pekerjaan sosial dengan individu (case work) adalah individualisasi, maksudnya ialah mereka yang mengalami masalah sosial harus dibantu sebagai perseorangan dan sebagai individu. (Najib, 2016). Oleh karena itu pekerja sosial percaya bahwa masalah sosial merupakan masalah individu, keterampilan-keterampilan prosedural juga penting yang perlu dipertajam secara sadar baik untuk kepentingan pekerja sosial sendiri maupun untuk diajarkan kepada klien.

Misalnya keterampilan mendengarkan, meminta tanggapan atau memulai percakapan, merefleksikan perasaan, mengumpulkan dan menginterpretasikan informasi, memberikan umpan balik dan lain sebagainya. Prinsip-prinsip tingkah laku juga penting dalam prinsipprinsip praktik yang dapat diterapkan dalam proses dan situasi pertolongan pekerjaan sosial, misalnya dalam berkomunikasi dengan klien, pekerja sosial hendaknya memberikan prioritas untuk membantu klien, pada tahap permulaan proses pertolongan pekerja sosial memberikan perhatian dan pertimbangan kepada tingkat kemampuan, kesanggupan persepsi serta harapanharapan dan kebutuhan-kebutuhan klien pada waktu itu sebagai fokus utama.

Yang mana usaha untuk terus membantu memperbaiki dan meningkatkan kemampuan komunikasi klien hendaknya dilakukan upaya secara khusus untuk menunjukkan kepada klien mengenai adanya pesan-pesan yang sifatnya kontradiktif yang mungkin dilakukan klien pada tingkat komunikasi yang berbeda-beda, dengan jalan demikian klien menjadi sadar terhadap pola-pola komunikasinya yang kurang baik dan tidak efektif. Menjadi pendengar yang baik hendaknya pekerja sosial menggunakan segenap indera sehingga dapat menangkap makna pesan-pesan yang disampaikan baik yang verbal maupun non verbal, mengingat para klien memiliki latar belakang budaya dan bahasa yang berbeda. Untuk itulah kemampuan atau keterampilan dalam mengembalikan keberfungsian sosial seseorang dalam memberi pertolongan secara efektif menuntut kompetensi komunikasi para pekerja sosial.

Para pekerja sosial yang ada di IPSM dalam penanganan pengemis harus mempunyai keterampilan komunikasi agar pengemis yang nantinya akan di mintai data dan akan di bina mau ikut serta dan tidak kabur ketika didekati, yaitu berupa kemampuan komunikasi interpersonal yang terjadi di antara dua orang. Komunikasi antar pribadi atau interpersonal communication merupakan proses komunikasi yang berlangsung antara dua orang atau lebih secara tatap muka dimana pengirim dapat menyampaikan pesan secara langsung dan penerima 
pesan dapat menerima dan menanggapi secara langsung (Cangara, 1998). Seluruh proses komunikasi terjadi di antara beberapa orang, namun banyak interaksi tidak melibatkan seluruh orang di dalamnya secara akrab. Proses komunikasi interpersonal menggambarkan terjadinya kegiatan komunikasi sebagai proses yang menghubungkan pengirim dengan penerima pesan. Dalam proses komunikasi interpersonal, komunikator memiliki peranan penting menentukan keberhasilan dalam mempengaruhi komunikan, berkaitan erat dengan karakter yang melekat pada komunikator itu sendiri. Maka dari itu, agar komunikasi interpersonal berjalan lancar dan mendatangkan hasil yang diterapkan, baik pemberi maupun penerima pesan perlu memiliki kemampuan dan komunikasi interpersonal yang diperlukan (Hardjana, 2003).

Dalam komunikasi interpersonal terdapat istilah mengacu pada kemampuan untuk berkomunikasi secara efektif (Cangara, 2004). Komunikasi interpersonal dapat meningkatkan hubungan kemanusiaan diantara pihak-pihak yang berkomunikasi. Dalam hidup bermasyarakat seseorang bisa memperoleh kemudahan dalam hidupnya karena memiliki pasangan hidup komunikator (Mulyana, 2000). Melalui komunikasi interpersonal juga dapat berusaha membina hubungan baik, sehingga menghindari dan mengatasi terjadinya konflikkonflik yang terjadi. Komunikasi Interpersonal dilakukan secara tatap muka, yang memungkinkan setiap pesertanya menangkap reaksi orang lain secara langsung, baik secara verbal ataupun non verbal (Arifin, 1994).

Secara keseluruhan, komunikasi interpersonal dapat dilakukan dengan baik dan tidak langsung media komunikasi langsung seperti tatap muka interaksi, serta komunikasi computer-mediated. Sukses mengasumsikan bahwa baik pengirim pesan dan penerima pesan akan menafsirkan dan memahami pesan-pesan yang dikirim pada tingkat mengerti makna dan implikasi. Tujuan komunikasi boleh jadi memberikan keterangan tentang sesuatu kepada penerima, mempengaruhi sikap penerima, memberikan dukungan psikologis kepada penerima atau mempengaruhi penerima. Konsep diri dan persepsi interpersonal sangat dibutuhkan untuk pencapaian dalam kelancaran komunikasi. Orang yang lancar dalam berkomunikasi berarti orang tersebut mempunyai keahlian dalam berkomunikasi. Persepsi interpersonal besar pengaruhnya bukan saja pada komunikasi interpersonal, tetapi juga pada hubungan interpersonal. Karena itu, kecermatan persepsi interpersonal akan sangat berguna untuk meningkatkan kualitas komunikasi interpersonal kita. Faktor-faktor personal yang mempengaruhi persepsi nterpersonal diantaranya adalah pengalaman, motivasi, kepribadian, stereotyping dan atribusi. Perilaku kita dalam berkomunikasi interpersonal amat bergantung pada persepsi interpersonal.

Jadi persepsi interpersonal membawa pengaruh yang besar bagi komunikasi interpersonal. Kegagalan komunikasi dapat diperbaiki apabila orang tersebut menyadari bahwa persepsinya salah. Adapun faktor-faktor menumbuhkan interpersonal dalam komunikasi interpersonal (Rakhmat, 1986): Percaya (Trust), sikap suportif, sikap terbuka.

Setiap komunikasi yang dilakukan, tentunya diharapkan menghasilkan sesuatu yang bermanfaat bagi siapa saja yang terlibat dalam komunikasi tersebut (Sutardi \& Budiasih, 2010). Komunikasi akan berjalan dengan dinamis, apabila disertai adanya suatu reaksi dari pihak penerima pesan. Reaksi ini menandakan bahwa pesan yang disampaikan mendapatkan tanggapan, komunikasi ini membutuhkan keterampilan latar belakang (background skills) 
presentasi, pemahaman tentang audiens, mendengarkan secara kritis, dan bahasa tubuh (body language).

Seperti kontek fenomena yang ada di lapangan yang dikatakan oleh bapak Slamet anggota Ikatan Pekerja Sosial Masyrakat (IPSM), ketika pekerja sosial menghampiri pengemis, para pengemis langsung kabur dan tidak sempat dimintai data, dikarenakan memakai atribut seperti topi yang ada logo IPSM nya, tetapi ada pengemis yang mau didekati, ketika mereka istirahat, para pekerja sosial ikut duduk disamping pengemis yang sedang makan di angkringan dan dengan menggunakan bahasa jawa, sehingga para pekerja sosial memperoleh data bahwa pengemis tersebut bersal dari Jombang (Slamet: 2018). Yang mana para pekerja sosialnya sebelum turun kelapangan tiga bulan sekali mendapatkan sosialisasi cara berkomunikasi dan mendekati para pengemis agar pengemisnya mau dibina dan menginformasikan dirinya.

Dari fenomena di atas, maka peneliti melihat kajian terdahulu seperti yang diteliti oleh Eti Nur Inah dengan judul Pola Komunikasi Interpersonal Kepala Madrasah Tsanawiyah Tridana Mulya Kecamatan Landono Kabupaten Konawe Selatan yang menghasilkan penelitian berupa pola komunikasi yang digunakan kepala Madrasah Tsanawiyah Tridana Mulya Kecamatan Landono adalah pola komunikasi linear, yaitu komunikasi yang dilakukan oleh kepala madrasah dengan cara memposisikan dirinya setara/ sederajat dengan guru. Serta terdapat faktor penghambat komunikasi interpersonal kepala sekolah dan guru adalah hambatan pekerjaan dari kepala madrasah dan masing-masing guru sehingga sulit menentukan waktu yang pas untuk menentukan waktu pelaksanaan komunikasi interpersonal.

Penelitian lainnya yakni dilakukan oleh Noor Ananda Masar dengan penelitin Strategi Komunikasi Lembaga Pemberdayaan Masyarakat (LPM) Dalam Mensosialisasikan Program Penghijauan Taman Kota Di Kelurahan Sanga-Sanga Dalam Kecamatan Sanga-Sanga Kabupaten Kutai Kartanegara yang mana hasil penelitian berupa menentukan khalayak dan menyeleksi pengguna media cetak. Masih sedikitnya pola komunikasi interpersonal yang diteliti dan ditulis oleh para peneliti terutama dalam bidang pemberdayaan dan sosial sehingga menggerakkan peneliti untuk melakukan penelitian dan menulis mengenai pola komunikasi dalam memberdayakan masyarakat yang tidak mampu. Yang di lakukan di IPSM melalui para pekerja sosial merupakan profesi untuk mengarahkan dan memperbaiki kondisi klien, serta mengurangi kesulitan-kesulitan yang bertujuan untuk memenuhi mandat kesejahteraan dan kualitas kehidupan masyarakat memerlukan keterampilan untuk mendekatkan diri kepada masyarakat melalui keterampilan komunikasi yang baik, maka peneliti tertarik untuk meneliti atau mengkaji lebih jauh tentang "Keterampilan Komunikasi Interpersonal Pekerja Sosial Dalam Menangani Pengemis Di IPSM Yograkarta".

\section{Metode}

Jenis penelitian yang digunakan dalam penelitian ini adalah deskriptif dengan menggunakan pendekatan kualitatif. Penelitian deskriptif adalah penelitian yang bertujuan menggambarkan secara tepat sifat-sifat suatu individu, keadaan, gejala, atau kelompok tertentu atau untuk melakukan penyebaran suatu gejala, atau untuk menentukan ada tidaknya hubungan antara suatu gejala dengan gejala lain dalam masyarakat metode penelitian 
kualitatif sering disebut metode penelitian naturalistik karena penelitiannya dilakukan pada kondisi yang alamiah (natural setting) (Sugiono, 2015). Penelitian deskriptif ditujukan untuk mendeskripsikan suatu keadaan atau fenomena-fenomena apa adanya (Sukamdinata, 2010).

Penelitian kualitatif lebih menekankan analisisnya pada proses penyimpulan deduktif dan induktif serta pada analisis terhadap dinamika hubungan antar fenomena yang diamati, dengan menggunakan logika ilmiah (Saifuddin, 2011). Lokasi dan waktu penelitian dilakukan di Ikatan Pekerja Sosial Masyarakat (IPSM) Yogyakarta. Informan penelitian merupakan Ketua serta staf Ikatan Pekerja Sosial Masyarakat (IPSM) dan pengemis di Yogyakarta. Teknik pengumpulan data menggunakan observasi yaitu teknik yang menuntut adanya pengamatan dari peneliti baik secara langsung maupun tidak langsung terhadap objek penelitian (Noor, 2016). Wawancara atau interview adalah suatu cara pengumpulan data yang digunakan untuk memperoleh informasi langsung dari sumbernya. (Indah, 2010) Dokumentasi adalah catatan peristiwa yang sudah berlalu, dokumen bisa berbentuk tulisan, gambar atau karya-karya monumental dari seseorang (Sugiono, 2015).

\section{Hasil dan Pembahasan}

\section{Keterampilan Komunikasi Interpersonal Pekerja Sosial dalam Menangani Pengemis di IPSM Yogyakarta}

Keterampilan pada hakikatnya adalah cara seseorang untuk melakukan sesuatu (Sutardi \& Budiasih, 2010). Setiap komunikasi yang dilakukan, tentunya diharapkan menghasilkan sesuatu yang bermanfaat bagi siapa saja yang terlibat dalam komunikasi tersebut. Komunikasi akan berjalan dengan dinamis, apabila disertai adanya suatu reaksi dari pihak penerima pesan. Reaksi ini menandakan bahwa pesan yang disampaikan mendapatkan tanggapan. Adapun jenis keterampilan komunikasi berupa keterampilan komunikasi lisan (oral communication) yaitu kemampuan berbicara (speaking) sehingga mampu menjelaskan dan mempresentasikan gagasan dengan jelas kepada bermacam-macam orang (audiens). Kemampuan ini meliputi keahlian menyesuaikan cara berbicara kepada komunikan yang berbeda, menggunakan pendekatan dan gaya yang pas, dan memahami pentingnya isyarat non verbal. Komunikasi ini membutuhkan keterampilan latar belakang (background skills) presentasi, pemahaman tentang audiens, mendengarkan secara kritis, dan bahasa tubuh (body language). Seperti yang dikatakan oleh bapak Kasman selaku ketua Ikatan Pekerja Sosial Masyarakat (IPSM) bahwa dalam menangani pengemis kami para pekerja sosial harus mempunyai keterampilan berkomunikasi, karena pengemis ketika hendak didekati langsung pergi, bahkan ketika sudah kita dekati tetapi dengan komunikasi yang tidak baik, maka pengemis tidak akan memberikan informasi kepada kami. (Kasman, 2018).

Keterampilan berkomunikasi yang diharapkan mencakup beberapa kemampuan yakni:

a. Kemampuan dalam menciptakan kontak atau hubungan interpersonal

Komunikasi interpersonal melibatkan pertukaran pesan baik pesan verbal maupun pesan non verbal. Kata-kata yang kita gunakan dalam komunikasi tatap muka dengan orang lain biasanya disertai dengan petunjuk non verbal seperti ekspresi wajah, kontak mata dan gerak tubuh atau bahasa tubuh. Berkomunikasi dengan orang lain merupakan hal yang sangat penting dalam kehidupan setiap manusia. Komunikasi sendiri 
merupakan suatu proses atau kegiatan penyampaian pesan dari seseorang kepada orang lain untuk mencapai tujuan tertentu. Tanpa adanya komunikasi, manusia tidak dapat membangun interkasi dan hubungan dengan orang lain. Seperti yang di katakan oleh bapak Slamet bahwa: "Komunikasi disini sangat penting tidak hanya dengan asal bertanya, tetapi melalui pendekatan, seperti dengan menggunakan bahasa yang mereka pakai, jadi mereka merasa mempunyai kedekatan yang lebih, ketika saya meng-asesmen pengemis yang berada di Stasiun Lempuyangan yang bernama Ibu Nani ia berasal dari Jombang dan terpaksa harus mengemis dikarenakan tidak mempunyai keahlian, di sini saya bisa memperoleh data karena saya mengetahui cara-cara masuk untuk bercerita dan memperoleh data kepada pengemis." (Slamet, 2018).

Fungsi komunikasi sendiri adalah untuk membangun diri kita sendiri dan juga orang lain. Melalui interaksi dengan orang lain kita akan merasa diakui di kehidupan sosial, merasa bahagia, menyampaikan perasaan dan mengenal siapa sesungguhnya diri kita. Melalui komunikasi kita juga dapat memberikan informasi, mengajar, mencapai tujuan bersama dan lain sebagainya. Namun banyak orang yang belum dapat berkomunikasi dengan baik dan efektif. Keterampilan komunikasi yang kurang baik dapat merusak suatu hubungan. Ada juga beberapa orang yang sulit untuk berkomunikasi dengan orang lain seperti yang dikatakan oleh Ibu Tia bahwa: "Ada beberapa pengemis yang ketika di dekati langsung kabur, dikarenakan kami datang berkelompok, jadi kami disini dalam memperoleh informasi harus secara interpersonal dan tidak berkelompok, pengemis akan merasa takut jika ramai-ramai dan bahkan pengemis memberikan identitas yang berbeda-beda, seperti Ibu Harariyah yang di tanya oleh IPSM lain tidak menyebutkan nama aslinya dan menyebut namanya Minah, namun ketika saya mendekatinya dengan bercerita ibu itu memberitahukan data dirinya bahwa nama aslinya adalah Harariyah seorang janda berusia 76 tahun, dan beralamat dikampung Celeban Kelurahan Tahunah Kecamatan UH anak dua, cucu delapan, dengan mengemis ibu itu Harariyah bertahan hidup." (Tia, 2018).

Dalam menerima pesan interpersonal melalui panca indera yang kita miliki seperti mendengar, melihat, mencium dan menyentuh. Kita bersikap diam pun sebenarnya mengirimkan suatu pesan interpersonal. Pesan-pesan yang disampaikan sebagian besar bergantung pada faktor-faktor lain yang terlibat dalam interaksi. Seperti yang dikatakan Bapak Slamet:

"Dalam memperoleh data kami juga memperhatikan interaksi baik, gerak tubuh, mimik wajah, melalui penglihatan dan pendengaran, dikarenakan pengemis yang ada terkadang tidak jujur ketika di tanya, terutama pengemis yang kami temui masih muda, dan yang tua juga terkadang linglung dan data yang di peroleh berbeda-beda, disinilah kami harus bisa memilih mana data yang benar mana yang tidak. (Slamet, 2018).

Dari hasil observasi yang penulis lihat bahwa para pekerja sosial mempunyai keterampilan yang mumpuni untuk meng-asesmen pengemis, sehingga data yang di peroleh akurat dan apabila besok bertemu dengan orang yang sama dan ditanyai berbeda identitas maka akan di lakukan pendekatan yang lebih instens dan tidak cukup dengan sekali dua kali sehingga data yang di peroleh akurat. 


\section{b. Kemampuan dalam menangkap atau memahami informasi}

Pemahaman merupakan salah satu patokan kompetensi yang dicapai setelah pekerja sosial melakukan kegiatan meng-asesmen pengemis. Dalam proses asesmen, setiap individu memiliki kemampuan yang berbeda-beda dalam memahami apa yang diberikan ketika diberikan pelatihan komunikasi interpersonal. Ada yang mampu memahami materi secara menyeluruh dan ada pula yang sama sekali tidak dapat dapat mengambil makna dari apa yang telah dipelajari, sehingga yang dicapai hanya sebatas mengetahui. Seperti yang di kata oleh bapak Kasman bahwa:

"Ada juga anggota Ikatan Pekerja Sosial Masyarakat (IPSM) yang tidak bisa meng-asesmen pengemis, data yang diperoleh tidak lengkap, mungkin ketidak diberikan sosialisasi mengenai keterampilan interpersonal untuk mendekati pengemis ada anggota yang tidak datang, jadi kesulitan dalam mengumpulkan data yang lengkap (Kasman, 2018).

Untuk itulah terdapat tingkatan-tingkatan dalam memahami informasi. Menurut Daryanto kemampuan pemahaman berdasarkan tingkat pemahaman dan derajat penyerapan materi dapat dijabarkan menjadi (Zuchdi, 1999):

a) Menerjemahkan (translation), berbagai macam suku yang menjadi pengemis di Yogyakarta dengan bahasa yang berbeda-beda, seperti yang dikatakan oleh Bapak Aji:

"Terkadang saya tidak begitu paham dengan bahasa yang digunakan oleh pengemis yang sudah tua, dikarenakan juga bahasanya menggunakan bahasa jawa halus dan saya terkadang sulit untuk memahami, seperti Ibu Lastri, ketika saya bertanya alamat yang ibu Lastri sampaikan mengenai anaknya yang sedang sakit, disini saya sebagai pekerja sosial turut berempati, tetapi saya terkendala dalam mendapatkan data dikarenakan sulit dalam menerjemahkan maksud dari ibu Lastri (Aji, 2018).

b) Mengekstrapolasi (extrapolation), Ekstrapolasi menuntut kemampuan intelektual yang lebih tinggi karena seseorang dituntut untuk bisa melihat sesuatu di bilik yang tertulis. Membuat ramalan tentang konsekuensi atau memperluas persepsi dalam arti waktu, kasus, ataupun masalahnya. Keterampilan pekerja sosial tidak hanya di lihat dari berkomunikasi terhadap pengemis tetapi juga bagaimana bisa membuat dugaan dan juga menyesuaikan dengan jawaban dan keadaan pengemis yang ada di lapangan. Membuat dugaan juga memerlukan seperti sikap terbuka. Sikap ini amat besar pengaruhnya dalam menumbuhkan komunikasi interpersonal yang efektif. Dengan komunikasi yang terbuka diharapkan tidak akan ada hal-hal yang tertutup, sehingga apa yang ada pada diri pengemis juga diketahui oleh pekerja sosial. Seperti yang dikatakan oleh Ibu Gani selaku pekerja sosial bahwa

"Ketika kami dilapangan dan setelah berkomunikasi dengan pengemis kami sudah membuat dugaan-dugaan sementara kepada para pengemis apakah yang dikatakan benar, apakah pengemis ini benar dari daerah Cirebon, apakah benar 
Namanya bapak Endang dan sebagainya, dikarenakan kami pernah menemui pengemis yang ketika di tanya lagi namanya berubah, maka dari itu kami mengasesmen tidak sekali dua kali, sehingga data yang didapat akurat, dan memastikan dugaan-dugaan sementara yang kami simpulkan (Gani, 2018).

Dari observasi yang penulis lihat bahwa para pekerja sosial dalam memperoleh informasi mempunyai keterampilan yang menuntut mereka untuk bisa melihat apakah pengemis ini jujur atau berbohong ketika diwawancarai, dan terbukti dari berbagai data yang diperoleh, para pekerja sosial mengetahui apakah pengemis itu berbohong atau tidak, dengan menemui orang yang sama dan di lakukan assesmen ulang dan hasilnya benar berbeda. Dan para pekerja sosial di Ikatan Pekerja Sosial Masyarakat (IPSM) sangat gigih dan tekun dalam melaksanakan tugasnya.

\section{c. Kemampuan dalam memberikan tanggapan atau umpan balik}

Umpan balik (feedback) merupakan tanggapan yang diberikan oleh seorang komunikan (penerima pesan) ketika seorang komunikator (pemberi pesan) sedang menyampaikan pesannya. Dalam arti singkat, feedback dapat dikatakan sebagai tanggapan atau respon terhadap suatu pesan, umpan balik diperlukan dari pekerja sosial kepada pengemis, seperti yang dikatakan oleh bapak Aji bahwa:

"Kita tidak mungkin diam saja ketika sudah bertanya kita memberikan umpan balik yang positif yang merupakan isyarat yang kita tunjukkan oleh pengemis yang menandakan bahwa pengemis memahami, membantu dan mau bekerja sama dengan pekerja sosial untuk mencapai sasaran komunikasi tertentu, dan tidak menunjukkan perlawanan ataupun pertentangan (Aji, 2018).

Dari observasi yang penulis lakukan ketika pekerja sosial melakukan pendekatan, mereka memberikan umpan balik yang negatif dengan gejala yang ditunjukkan oleh pengemis menandakan bahwa mereka memiliki sikap serta perilaku yang dapat berkisar dari mulai tidak setuju hingga tidak menyukai pesan, cara penyampaian, seprti sikap acuh tak acuh, melakukan hal lain yang tidak ada hubungannya dengan yang sedang dibahas, mengobrol, mengganggu orang lain, nyeletuk, memotong pembicaraan.

\section{d. Kemampuan dalam mengarahkan orang lain untuk melakukan sesuatu}

Proses komunikasi interpersonal menggambarkan terjadinya kegiatan komunikasi sebagai proses yang menghubungkan pengirim dengan penerima pesan. Dalam proses komunikasi interpersonal, komunikator memiliki peranan penting menentukan keberhasilan dalam mempengaruhi komunikan, berkaitan erat dengan karakter yang melekat pada komunikator itu sendiri. Hal yang dilakukan agar interpersonal berjalan lancar dan mendatangkan hasil yang diterapkan, baik pemberi maupun penerima pesan perlu memiliki kemampuan dan komunikasi interpersonal yang diperlukan (Hardjana, 2003). Seperti yang di katakan oleh bapak Kasman: "Perlunya berbagai keterampilan mendekatkan diri pada pengemis berkaitan dengan karakter pekerja sosial, apabila 
pekerja sosial bisa membawakan diri kepada pengemis maka informasi yang di perlukan akan didapatkan dengan mudah.” (Kasman, 2018).

Usaha mempengaruhi dan mengarahkan pengemis tidaklah mudah maka harus mempunyai trik dan keahlian sehingga pengemis mau bercerita dan memberikan informasi yang kita butuhkan. Seperti yang dikatakan oleh Ibu Tia bahwa:

Dalam mengarahkan pengemis untuk mau berkomunikasi dan memberikan informasi yang cukup tidaklah mudah, tetapi dengan pendekatan dan tidak langsung bertanya memulai dengan bahasa dan pembahasan yang ringan maka akan kita peroleh data yang lengkap, bahkan seperti bapak Endang Lilih Sadeli yang mau memberikan informasi mengenai data dirinya bahkan mau untuk menunjukkan kartu tanda penduduk (KTP) dan mau di foto, bapak Endang Lilih Sadeli berasal dari kabupaten Ciamis yang bekerja sebagai pengemis di Yogyakarta, bapak Endang Lilih Sadeli mengaku bahwa lebih gampang meminta-minta dan lapangan pekerja yang sulit membuat ia menjadi pengemis (Tia, 2018).

Data di atas ini menunjukkan bahwa ibu Tia selaku pekerja sosial bisa mengarahkan pengemis untuk memberikan identitas dan data diri, yang mana bisa mengatur hubungan antara individu. Selain dalam mempengaruhi dan mengarahkan individu atau kelompok bertujuan untuk membantu para pekerja sosial untuk bergerak ke arah pencapaian sasaran. Dengan demikian, kemampuan mengarahkan orang lain bukan pertama-tama terletak pada kedudukannya dalam menjalankan tugas tetapi bagaimana berinteraksi dengan pengemis yang ada.

Salah satu yang terpenting adalah menumbuhkan kepercayaan pengemis kepada pekerja sosial, kepercayaan (Trust) dari berbagai faktor yang paling mempengaruhi komunikasi antar pribadi adalah faktor kepercayaan. Apabila antara pekerja sosial dan pengemis memiliki rasa saling percaya, maka akan terbentuk sikap saling terbuka dan terhindar dari kesalah pahaman. Sejak tahap perkenalan dan tahap peneguhan, kepercayaan menentukan efektivitas komunikasi.

\section{Simpulan}

Dalam Penelitian Keterampilan Komunikasi Interpersonal Pekerja Sosial dalam Menangani Pengemis di IPSM Yogyakarta dapat disimpulkan bahwa para pekerja sosial dalam menangani pengemis di Ikatan Pekerja Sosial Masyarakat menggunakan berbagai keterampilan interpersonal berupa kemampuan dalam menciptakan kontak atau hubungan interpersonal, yang mana pekerja sosial mendekatkan diri kepada pengemis secara individu atau interpersonal serta tatap muka dan tidak bekelompok sehingga memudahkan pekerja sosial untuk mendekati pengemis serta menggunakan bahasa daerah yaitu jawa dalam pendekatan kepada pengemis yang berasal dari jawa, yang kedua pekerja sosial mampu menangkap atau memahami informasi dari pengemis, walaupun ada beberapa pengemis yang sulit dipahami dikarenakan memberikan data identitas yang berubah-ubah terutama pengemis yang lansia, selanjutnya kemampuan dalam memberikan tanggapan atau umpan balik, kemampuan dalam mengarahkan orang lain untuk melakukan sesuatu dilakukan oleh para pekerja sosial dengan memberikan tanggapan dan respon positif, serta menjadi pendengar 
yang baik dilihat dari pengemis yang mau menunjukkan KTP tanpa menaruh curiga kepada pekerja sosial, hal ini dilihat dari gerak gerik dan juga pengamatan yang dilakukan oleh para pekerja sosial terhadap tingkah laku pengemis.

\section{Referensi}

Andrisman, T. (2013). Hukum Peradilan Anak. Bandar Lampung: Bagian Hukum Pidana Fakultas Hukum UNILA.

Arifin, A. (1994). Strategi Komunikasi; sebuah Pengantar Ringkas. Cetakan Ketiga. Bandung: CV Armico

Barsky, A. E. (2010). Ethics and Values in Sosial Work: An Integrated Approach for a Comprehensive Curriculum. New York: Oxford University Press.

Cangara, H. (1998). Pengantar Ilmu Komunikasi. Jakarta: PT. Raja Grafindo Persada

Departemen Sosial R.I. (2007). Standard Pelayanan Minimal Pelayanan dan Rehabilitasi Sosial Gelandangan dan Pengemis.

Gaarder, J. (2015). Dunia Sophie. Penerjemah: Rahmani Astuti, cetakan ke XVI Edisi Gold. (Yogyakarta: Mizan)

Cangara, H. (2004). Pengantar Ilmu Komunikasi. (Jakarta : PT Raja Grafindo Persada)

Irwan, S \& Suardi. (2016). Mengemis Sebagai Suatu Pekerjaan, (Jurnal Equilibrium Pendidikan Sosiologi Volume IV No. 1 Mei 2016 ISSN e-2477-0221 p-2339-2401)

Jahidin, A. (2016). Epistemologi Ilmu Kesejahteraan Sosial Perjalanan Dialektika Memahami Anatomi Pekerjaan Sosial Profesional. Yogyakarta: Samudra Biru

Juliansyah, N. (2016). Metodologi Penelitian Skripsi, Tesis, Disertasi, dan Karya Ilmiah. Jakarta: Kencana Prenada Media Group

Khan MM, M, Hasina N. Status and Social Evaluation towards Beggars in Bangladesh: Context of Sykhet City. Juni 2016, dalam International Journal of Sosial Science Studie, Vol 4, No.6.

Hardjana, A. M. (2003). Komunikasi Intrapersonal \& Interpersonal. Yogyakarta: Penerbit Kanisius)

Meilia, N. I. (2010). Statistik Deskriptif dan Induktif. Yogyakarta: Graha Ilmu

Mulyana, D. (2000). Ilmu Komunikasi Suatu Pengantar. Bandung: PT. Remaja Rosdakarya

Najib, A. (2016). Integrasi Pekerjaan Sosial Pengembangan Masyarakat dan Pemberdayaan Masyarakat. Yogyakarta: Semesta Ilmu

Oktaviana, Z., \& Meitriana. (2014). Pengemis dan Upaya Penanggulangannya (Studi Kasus di Desa Rarang Tengah Kecamatan Terara Kabupaten Lombok Timur). Dalam Jurnal Pendidikan Ekonomi UNDIKSHA Vol: 4 No: 1.

Rakhmat, J. (1986). Psikologi Komunikasi. Bandung: Remaja Rosdakarya, Cetakan Kedua Saifuddin, A. M. (2011). Metode Penelitian. Yogyakarta: Pustaka Pelajar Sugiono (2015). Memahami Penelitian Kualitatif. Bandung: Alfabeta

Suharto, E. (2009). Membangun Masyarakat, Memberdayakan Rakyat. Bandung: PT.Refika Aditama.

Sukamdinata, N. S. (2010). Metode penelitian pendidikan. Bandung: PT Remaja Rosdakarya 
Sutardi, A., \& Budiasih, E. (2010). Mahasiswa Tidak Memble Siap Ambil Alih Kekuasaan Nasional. Jakarta: PT Elex Media Komputindo

Taftazani, M. B. (2014). Teori Pekerjaan Sosial Dalam Lintasan Modernisme Dan Posmodernisme dalam social work journal. Vol. 4. No. 2

Tangdilintin, P. (2000). Masalah-Masalah Sosial (Suatu Pendekatan Analisis Sosiologis). Jakarta: Pusat Penerbitan Universitas Terbuka

Zuchdi, D. (1999). Strategi Meningkatkan Kemampuan Membaca. Yogyakarta: UNY Press

Wawancara:

Bapak Aji. Anggota IPSM Yogyakarta. 9 November 2018. 13.00 WIB di Ring Road Utara Yogyakarta

Bapak Kasman. Ketua IPSM Yogyakarta. 5 November 2018, 13.00 WIB di IPSM Yogyakarta

Bapak Slamet. Anggota IPSM Yogyakarta. 9 November 2018. 13.00 WIB di Ring Road Utara Yogyakarta

Ibu Tia. Anggota IPSM Yogyakarta. 12 November 2018. 14.00 WIB di Jalan Malioboro Yogyakarta

Ibu Gani. Anggota IPSM Yogyakarta. 12 November 2018. 16.00 WIB di Jalan Malioboro Yogyakarta 